University of Nebraska - Lincoln

DigitalCommons@University of Nebraska - Lincoln

Court Review: The Journal of the American

Judges Association

American Judges Association

2009

Apologies and Settlement

Jennifer K. Robbennolt

University of Illinois College of Law

Follow this and additional works at: https://digitalcommons.unl.edu/ajacourtreview

Robbennolt, Jennifer K., "Apologies and Settlement" (2009). Court Review: The Journal of the American Judges Association. 296.

https://digitalcommons.unl.edu/ajacourtreview/296

This Article is brought to you for free and open access by the American Judges Association at DigitalCommons@University of Nebraska - Lincoln. It has been accepted for inclusion in Court Review: The Journal of the American Judges Association by an authorized administrator of DigitalCommons@University of Nebraska -

Lincoln. 


\section{Apologies and Settlement}

Jennifer K. Robbennolt

$\mathbf{W}$ hen one person allegedly injures another, he or she will often attempt to provide an account for the conduct that led to the injury. Specifically, he or she might attempt to disavow, explain, excuse, or justify the behavior that purportedly led to the injury. Alternately, he or she might offer an apology to the injured person. Apologies can be distinguished from other forms of accounting in that they acknowledge responsibility for the conduct that caused the harm. Accepting blame and expressing regret for one's behavior signals a recognition of the norm or rule that was violated and of the harm caused to the other. ${ }^{1}$

Such acknowledgment can be complicated in the context of litigation. When the offense is such that it raises the possible involvement of the legal system, defendants, defense counsel, and insurance companies have traditionally worried that apologizing will only make things worse for the defendant; specifically, that any apology will be viewed as an admission and will lead to more certain legal liability. ${ }^{2}$ Indeed, there is evidence that although civil defendants, such as physicians in medical malpractice cases, may sometimes desire to offer apologies, they are also concerned that disclosure or acceptance of responsibility would increase the possibility for legal liability. ${ }^{3}$

As a general matter, of course, an apology by a party to litigation is potentially admissible under the exception to the hearsay rule that allows admission of a party's own statements. Other rules of evidence may prevent the admission of certain apologetic statements in some circumstances - for example, statements made in settlement discussions may be protected under Rule 408. However, apologies that are made outside of these contexts are potentially admissible. Consequently, many defendants avoid apologizing and are so counseled by their attorneys and insurers.

Despite the potential risks, however, there has been growing interest in the possibility that clients might benefit, legally and otherwise, from apologizing. ${ }^{4}$ Indeed, empirical studies examining the impact of apologies in a variety of contexts have demonstrated a range of positive effects that flow from apologizing. These effects include more favorable attributions, more positive and less negative emotion for both apologizer and recipient, improved physiological responses for both parties, improved future relations, decreased need to punish, and more likely forgiveness. In addition to the potential physical, psychological, and relational benefits of apologies, commentators have argued that apologies have the potential to facilitate the settlement of legal disputes-breaking impasse to allow productive negotiation, allowing resolution to occur more quickly, addressing parties' non-legal concerns, or resulting in financial settlement terms that are more favorable to the one who has apologized.

Some proponents of encouraging apologies in litigation have considered how defendants who desire to apologize might do so "safely" given the patchwork of evidentiary protection traditionally available. One recommendation has been that defendants consider offering statements that express sympathy for the other party, but that stop short of admitting responsibility for having caused injury (i.e., "I'm sorry you were hurt" rather than "I am sorry I hurt you."). These sympathetic expressions are not complete apologies by most definitions-lacking, in particular, an acknowledgment of responsibility for the behavior that led to the harm. However, it is argued that by offering at least an expression of sympathy, defendants can reap some of the benefits of apologizing while simultaneously minimizing any increase in liability risk.

Concurrently, many states have recently enacted statutes that are intended to encourage and protect certain apologetic expressions by making them inadmissible in court. Massachusetts enacted the first statute preventing the admission of some apologies in $1986 .{ }^{5}$ Since then, over two-thirds
Authors' Note: This work was supported by the National Science Foundation under Grant No. 0241355, the University of Illinois College of Law, and the University of Missouri Law School Foundation, and benefited greatly from the helpful comments of Judge Andrew Wistrich. This article is adapted from Jennifer K. Robbennolt, Attorneys, Apologies, and Settlement Negotiation, 13 HARV. NEGOt. L. REV. 349 (2008).

\section{Footnotes}

1. See generally Nicholas Tavuchis, Mea Culpa: A Sociology of Apology AND ReCOnCiliation (1991).

2. It is worth noting that, empirically, it is not clear whether, under what circumstances, or to what degree an apology might alter the risk of an adverse liability determination. Whether apologies influence liability decision making in civil cases has not been examined in empirical studies. On one hand, in the criminal context, confession evidence has been shown to exert a powerful effect on decision making. See e.g., Saul Kassin \& Gisli H. Gudjonsson, The Psychology of Confessions: A Review of the Literature and Issues, 5 Psychol. Sci. Pub. Int. 33 (2004); Saul M. Kassin \& Katherine Neumann, On the Power of Confession
Evidence: An Experimental Test of the Fundamental Difference Hypothesis, 21 Law \& Hum. BeHav. 469 (1997). On the other hand, studies examining attributions of responsibility in nonlegal contexts have found that offenders who apologize are seen as having acted less intentionally and are blamed less. See e.g., Steven J. Scher \& John M. Darley, How Effective Are the Things People Say to Apologize? Effects of the Realization of the Apology Speech Act, $26 \mathrm{~J}$. Psycholinguistic Res. 127 (1997).

3. Thomas H. Gallagher et al., Patients' and Physicians' Attitudes Regarding the Disclosure of Medical Errors, 289 JAMA 1001 (2003).

4. See, e.g., Jonathan R. Cohen, Advising Clients to Apologize, 72 S. CAL. L. Rev. 1009 (1999); Erin Ann O'Hara \& Douglas Yarn, On Apology and Consilience, 77 WAsh. L. Rev. 1121 (2002); Aviva Orenstein, Apology Excepted: Incorporating a Feminist Analysis into Evidence Policy Where You Would Least Expect It, 28 Sw. U. L. REv. 221 (1999); Daniel Shuman, The Role of Apology in Tort Law, 83 Judicature 180 (2000); Lee Taft, Apology Subverted: The Commodification of Apology, 109 Yale L.J. 1135 (2000).

5. Mass. Gen. Laws Ann. CH. 233, § 23D (West 1986). 
of the states have followed suit and have enacted statutes that explicitly provide some apologies with evidentiary protection (see Appendix). Many of these statutes apply to civil litigation generally; others apply specifically to cases of medical error. In addition, these statutes vary as to the type of apologetic statements that are protected. For example, some statutes only prevent the admission of those statements that express sympathy (i.e., "I'm sorry that you were hurt."), while preserving the admissibility of any statement that acknowledges fault (i.e., "It was my fault."). Other statutes have gone further, also providing protection to statements that express "fault," "error," or "mistake." Still other statutes protect "apologies" without clearly defining the term.

Proponents of these protected apologies suggest that if the law prevents the admission of apologetic expressions, defendants will be more likely to offer them. However, whether these apology statutes will result in more apologies and what form such apologies might take are open empirical questions. Many argue that apologies are impeded by the fear of litigation generally, and the fear that an apology will increase the risk of liability more specifically. However, other cultural and psychological barriers to apologizing operate as well. Apologies are difficult to make-admitting that one's behavior has caused harm and apologizing for it is embarrassing and injurious to one's pride. Nancy Berlinger recognizes the role that these other obstacles to apologies may play when she notes that "merely protecting apologies is not the same as encouraging them. Genuine apologies are never fun to make."6

Critics of providing evidentiary protection for apologies recognize the possibility that allowing apologies to be introduced against the apologizer in a subsequent legal proceeding could have a "chilling effect" on such expressions of remorse, but argue that removing the legal consequences of apologizing would diminish the moral content of the apology.7 Others, however, argue that even legally protected apologies are socially useful, can promote settlement, and should be encouraged (or at least not discouraged).

Recent empirical work has begun to explore the role of apologies in the civil justice system and to examine the nuances of the ways in which apologies may influence the resolution of legal disputes. This body of work suggests that apologies have a role to play in fostering settlement, but that the complexities of the apologies, the context in which they are offered, and whether the apology is being evaluated by a claimant, attorney, or judge, may moderate the ways in which apologies influence settlement.

\section{EXAMPLES OF APOLOGY LEGISLATION}

- Statements, writings, or benevolent gestures expressing sympathy or a general sense of benevolence relating to the pain, suffering or death of a person involved in an accident and made to such person or to the family of such person shall be inadmissible as evidence of an admission of liability in a civil action. MAss. GEN. LaWS AnN. СH. 233, § 23D (West 1986).

- The portion of statements, writings, or benevolent gestures expressing sympathy or a general sense of benevolence relating to the pain, suffering, or death of a person involved in an accident and made to that person or the family of that person shall be inadmissible as evidence of an admission of liability in a civil action. A statement of fault, however, which is part of, or in addition to, any of the above shall not be inadmissible pursuant to this section. Cal. Evid. Code \& 1160(a) (2000).

- In any civil action brought by an alleged victim of an unanticipated outcome of medical care, or in any arbitration proceeding relating to such civil action, any and all statements, affirmations, gestures, or conduct expressing apology, fault, sympathy, commiseration, condolence, compassion, or a general sense of benevolence which are made by a health care provider or an employee of a health care provider to the alleged victim, or a representative of the alleged victim and which relate to the discomfort, pain, suffering, injury, or death of the alleged victim as the result of the unanticipated outcome of medical care shall be inadmissible as evidence of an admission of liability or as evidence of an admission against interest. Colo. Rev. Stat. \& 13-25-135 (2003).

\section{CLAIMANTS AND APOLOGIES}

As an initial matter, people anticipate that they would desire an apology if they were injured by another. A number of studies have found that medical patients report that they would want to receive an apology from their physician if the physician made a mistake. ${ }^{8}$ In addition, studies that have asked litigants about their motives for bringing suit find that many of these plaintiffs believe that an apology from the other side is one factor that might have changed the course of the litigation. ${ }^{9}$
6. Nancy Berlinger, After Harm: Medical Error and the Ethics of FORGIVENESS 62 (2005).

7. Taft, supra note 4 .

8. See, e.g., Gallagher et al., supra note 3; Kathleen M. Mazor et al., Health Plan Members' Views About Disclosure of Medical Errors, 140 Annals Internal Med. 409 (2004); Amy B. Witman et al., How Do Patients Want Physicians to Handle Mistakes? A Survey of Internal Medicine Patients in an Academic Setting, 156 ArCHIVES INTERNAL MED. 2565 (1996).
9. Gerald B. Hickson et al., Factors that Prompted Families to File Medical Malpractice Claims Following Perinatal Injuries, 267 JAMA 1359 (1992); John Soloski, The Study and the Libel Plaintiff: Who Sues for Libel?, 71 IowA L. Rev. 217 (1985); Charles Vincent et al., Why Do People Sue Doctors? A Study of Patients and Relatives Taking Legal Action, 343 LANCET 1609 (1994). 


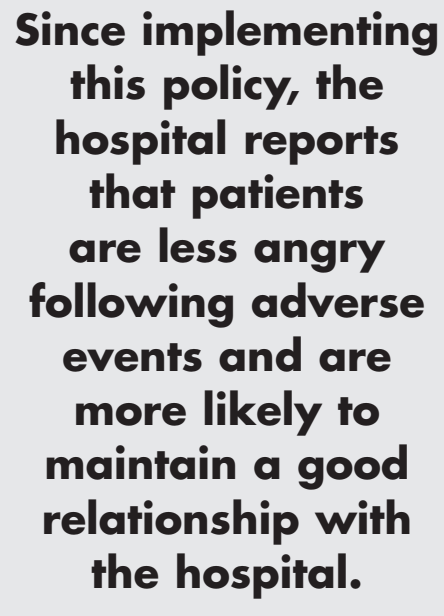
and an offer of settlement made. Since implementing this policy, the hospital reports that patients are less angry following adverse events and are more likely to maintain a good relationship with the hospital. The hospital also reports that cases settle more quickly, self-reporting of errors by the medical professionals has increased, the hospital has received positive publicity, and litigation costs have declined. ${ }^{10}$ Other institutions (e.g., University of Michigan Health System, John's Hopkins, Children's Healthcare of Atlanta, Sturdy Memorial Hospital in Boston) as well as private insurers (e.g., COPIC) have adopted similar policies and report similarly positive results. ${ }^{11}$

In addition to this data from the field, experimental research has provided insight into the processes by which apologies can influence the ways in which injured parties construe an injuryproducing incident and, thus, their willingness to settle. Specifically, these experiments find that apologies influence a variety of litigation related judgments and decisions, including the inclination to seek legal advice, the positions taken in settlement negotiations, and the likelihood of accepting a particular settlement offer.

In one study, Kathleen Mazor and her colleagues explored patients' decisions about whether to obtain legal advice following a medical injury. ${ }^{12}$ Members of an insurance plan were asked to take the perspective of a patient who had been injured by a medical error. Participants were either told that following the error the physician provided little information and did not take responsibility for the error (the "nondisclosure" condition) or were told that the physician provided information about what had happened, apologized, and took responsibility for the error, and detailed steps that would be taken to prevent recurrence (the "full disclosure" condition). Patients who were told that the physician had provided full disclosure and an apology following the error expressed greater satisfaction and fewer negative emotions, reported more trust in the physician, were less likely to indicate that they would change doctors, and were less likely to indicate that they would seek legal advice in response to the incident than were patients whose physician had not disclosed and apologized.

Professors Russell Korobkin and Chris Guthrie conducted an experimental investigation of the effects of an apology on litigants' settlement decisions in a landlord-tenant dispute..$^{13}$ Participants were asked to assume the role of the tenant in a dispute between a landlord and tenant over a broken heater and to evaluate a particular offer of settlement from the landlord. Participants who were told that the landlord had apologized to them were marginally more likely to accept the landlord's offer than were participants who had not received an apology.

Similarly, I conducted a series of studies to examine how laypeople in the role of an injured party respond to apologies in making settlement decisions. ${ }^{14}$ Participants were asked to respond to a scenario in which they were injured in a bicyclepedestrian collision. The other party offered either a partial apology, which consisted of an expression of sympathy but no acceptance of responsibility, a full, responsibility-accepting apology, or no apology. Apologies, particularly those that accepted responsibility for having caused injury, favorably influenced a variety of attributions made about the situation and the other party, including perceptions of the character of and the degree of regret experienced by the other party, expectations about the way in which the other party would behave in the future, and expectations about the relationship between the parties going forward. Similarly, apologies influenced the emotions that participants reported they would feel-decreasing anger toward the other party and increasing sympathy for the other's position. Full, responsibility-accepting apologies showed these effects consistently. Apologies that merely expressed sympathy were more context dependent, favorably influencing these attributions under some circumstances, but not in others.

These studies also found that apologies influence judgments that are directly related to legal-settlement decision making. Many studies have demonstrated that the value that a negotiator sets as his or her reservation price (or "bottomline"), the negotiator's aspirations, and the negotiator's judgment about what a fair settlement would entail, all influence
10. See Jonathan R. Cohen, Apology and Organizations: Exploring an Example from Medical Practice, 27 Fordham URB. L.J. 1447 (2000); Steve S. Kraman, A Risk Management Program Based on Full Disclosure and Trust: Does Everyone Win?, 27 CompreHENSIVE Therapy 253 (2001); Steve S. Kraman \& Ginny Hamm, Risk Management: Extreme Honesty May Be the Best Policy, 131 Annals INTERNAL MED. 963 (1999)

11. See Rae M. Lamb et al., Hospital Disclosure Practices: Results of a National Survey, 22 Health AfF. 73 (2003); Virginia L. Morrison, Heyoka: The Shifting Shape of Dispute Resolution in Health Care, 21 GA. St. U. L. Rev. 931 (2005); Rachel Zimmerman, Medical Contrition: Doctors' New Tool to Fight Lawsuits: Saying 'I'm Sorry,'
Wall Street J., May 18, 2004, at Al; see also Sorry Works!, http://www.sorryworks.net (last visited Feb. 9, 2009).

12. Mazor et al., supra note 8; Kathleen M. Mazor et al., Disclosure of Medical Errors: What Factors Influence How Patients Respond? $21 \mathrm{~J}$. Gen. Internal Med. 704 (2006).

13. Russell Korobkin \& Chris Guthrie, Psychological Barriers to Litigation Settlement: An Experimental Approach, 93 MicH. L. Rev. 107 (1994).

14. Jennifer K. Robbennolt, Apologies and Legal Settlement: An Empirical Examination, 102 Mich. L. REV. 460 (2003); Jennifer K. Robbennolt, Apologies and Settlement Levers, 3 J. EMPIRICAL LEGAL STUD. 333 (2006). 
final negotiated outcomes. In my studies, there were circumstances under which claimants who received an apology had lower aspirations and set lower values for their judgments about what would be a fair settlement value.

Similarly, apologies influenced how individuals evaluated a settlement offer in terms of its ability to make up for the harm suffered, how they appraised their need to punish the other party, and how they assessed their willingness to forgive the other party. Participants receiving apologies judged an offer as being more adequate, felt less need to punish the other party, and were more willing to forgive than were participants who did not receive apologies. Finally, full, responsibility-accepting apologies increased the tendency of recipients to accept a particular settlement offer. Interestingly, none of these judgments or decisions were systematically influenced by variations in the evidentiary rule governing apologies.

Thus, there is evidence that apologies are valued by claimants and that apologies may help to facilitate settlement. However, in addition to the hope that apologies may facilitate settlement, much concern has been expressed about the possibility that plaintiffs will be taken advantage of by insincere apologies or that plaintiffs are not attentive enough to law (e.g., evidentiary rules) and will improvidently forfeit legal entitlements. In particular, there is concern that plaintiffs will be "duped by communication strategies into relinquishing valuable legal rights, which can actually exacerbate the economic dimension of suffering." 15 While strategic or insincere apologies may still serve some goals that plaintiffs have (e.g., serving to acknowledge the wrong), such apologies may fail to serve other plaintiff goals (e.g., achieving a change in behavior).

If litigants are able to detect and reject insincere apologies, there might be less cause for concern. This is because the perceived sincerity of an apology can matter to its recipients. People do not have the same favorable responses to explicitly insincere apologies that they have to sincere apologies, ${ }^{16}$ and insincere apologies may actually cause people to react negatively. ${ }^{17}$ Thus, as Professor Dale Miller has argued, when injured parties "perceive apologies to be insincere and designed simply to 'cool them out,' they often react with more rather than less indignation." 18

It is not clear, however, how well injured litigants are able to detect and respond to insincerity, particularly when efforts are made to appear sincere. ${ }^{19}$ On the one hand, claimants are sensitive to the differences in content conveyed by apologies that accept responsibility for having caused harm and statements that only express sympathy for injuries. ${ }^{20}$ Similarly, the effectiveness of apologies is influenced by a variety of factors that might be seen as signals to the sincerity of the apology. Thus, apologies that include promises to forbear from similar wrongful conduct in the future, apologies that are accompanied by offers of compensation, and apologies that are properly timed all produce more favorable reactions than apologies without these features. These factors may operate, at least in part, by altering the perceived sincerity of the apology.

On the other hand, there is also evidence that people respond favorably even to apologies that seem to be insincere and that those who reject apologies, even unconvincing apologies, are judged less favorably than those who accept them. ${ }^{21}$ Thus, an apology "script" that contemplates that an apology will be followed by acceptance of that apology may hold sway over apology recipients' behavior. In addition, norms of reciprocity may prescribe the acceptance of apologies. The reciprocity norm demands "that we should try to repay, in kind, what another person has provided us."22 Concessions offered by one party to a negotiation trigger, under this norm, the obligation to make a reciprocal concession. If an apology offered by a defendant is viewed as a "concession," victims and observers may respond favorably because they feel an obligation to respond with a reciprocal "concession" of their own.

Finally, as noted above, there is no evidence that laypeople distinguish among apologies that are offered in the face of differing rules of evidence. ${ }^{23}$ Litigants may focus on personal factors (e.g., this person must be sorry) to the neglect of situational factors (e.g., this apology didn't cost them anything) when making causal attributions about the apologetic behav-
15. Lee Taft, On Bended Knee (With Fingers Crossed), 55 DePAul L. Rev. 601, 609 (2005-2006).

16. See Edward C. Tomlinson et al., The Road to Reconciliation: Antecedents of Victim Willingness to Reconcile Following a Broken Promise, 30 J. Mgmt. 165 (2004).

17. See, e.g., Daniel P. Skarlicki et al., When Social Accounts Backfire: The Exacerbating Effects of a Polite Message or an Apology on Reactions to an Unfair Outcome, 34 J. Applied Soc. Psychol. 322 (2004). See also Robbennolt, Apologies and Legal Settlement, supra note 14 .

18. Dale T. Miller, Disrespect and the Experience of Injustice, 52 AnN. Rev. Psychol. 527, 538 (2001).

19. Compare William Ian Miller, Faking It 78 (2003) (arguing that apologies are easy to "fake") and Jeffrie G. Murphy, Remorse, Apology, and Mercy, 4 OHIO St. J. CRIM. L. 423 (arguing that remorse and repentance are easy to fake) with Orenstein, supra note 4 (arguing that "the emotion of contrition is hard to fake in person").

20. Robbennolt, Apologies and Legal Settlement, supra note 14.

21. See Mark Bennett \& Christopher Dewberry, "I've said I'm sorry, haven't I?" A Study of the Identity Implications and Constraints that Apologies Create for Their Recipients, 13 Current Psychol. 10 (1994); Jane L. Risen \& Thomas Gilovich, Target and Observer Differences in the Acceptance of Questionable Apologies, $92 \mathrm{~J}$. Personality \& Soc. Psychol. 418 (2007).

22. See Robert B. Cialdini, Influence: Science and Practice 19 (1993).

23. Robbennolt, Apologies and Legal Settlemen, supra note 14; Robbennolt, Apologies and Settlement Levers, supra note 14. Note, however, that an apology can be sincerely offered even though it is subject to a rule protecting it. 


Importantly, there
are a number of
reasons that
attorneys might
be expected to
have different
responses to
apologies than
do laypeople.

gies offered in settlement nego-

tiation. The litigants themselves, however, are not the only legal actors involved in legal-settlement decision making. Legal negotiation is often characterized by the involvement of attorneys in the negotiation process. While the client, not the attorney, is supposed to make the ultimate decision about whether to accept or reject a settlement offer, attorneys are likely to have considerable influence on the client's settlement decisions. Clients look to their attorneys for advice and rely on them for knowledge of the substantive rules governing the case, their understanding of the processes involved, and their expertise as negotiators.

Given the presence of lawyers in much legal negotiation and their influence on client decision making, it is important to understand the effects that apologies might have on the settlement recommendations that attorneys make to their clients. Importantly, there are a number of reasons that attorneys might be expected to have different responses to apologies than do laypeople.

First, attorneys may respond differently to apologies for reasons attributable to their role as agent, rather than as a party to the underlying dispute. Attorneys as agents are likely to be more detached from the interpersonal aspects of the dispute as they have neither been injured nor alleged to have done the injuring, and the relationships at issue are not their own. This detachment may enable the attorney to manage the conflict in a way that avoids the barriers to settlement that may result from an emotionally charged atmosphere, and may also lead the attorney to respond differently than the client would have to the psychological and emotional aspects of the dispute and to place different emphasis on the importance of an apology. Moreover, recent research that has shown that observers are more likely to distinguish between sincere and insincere apologies than are the direct recipients of apologies. In contrast to direct recipients, observers do not feel obligated to credit insincere apologies, and when observers do reject such apologies they do not expect to be and are not judged more harshly. ${ }^{24}$ Thus, the social constraints that may limit recipients' responses to apologies do not appear to operate the same way when it comes to third-party observers.

A separate set of role effects may be related to the ways in which attorneys are compensated. Plaintiffs' attorneys, who are often compensated by a contingency fee, may not be inclined to negotiate lower monetary settlements in light of apologies, while defense attorneys, who are more likely to be compensated by an hourly fee, may not be eager to speed settlement of a case with an apology. At the same time, however, it is argued that contingency fee lawyers have incentives to settle cases quickly, and apologies may be consistent with that end.

Second, there is evidence that attorneys are selected and trained to be more analytical and less emotional in their general approach to settlement than are their clients. ${ }^{25}$ Of particular relevance to how attorneys and clients will respond to apologies in litigation, there is evidence that lawyers may be less influenced by concerns for equity or vindication and more concerned with expected value analysis in responding to settlement offers than are litigants. ${ }^{26}$

Third, attorneys may have a more heightened focus on protecting legal rights than do their clients. Indeed, one study found that the lawyers studied believed that one of the most fundamental roles they served as legal professionals was their service as "watchdogs" who are concerned with protecting their clients' legal entitlements. ${ }^{27}$ In particular, attorneys may have a better sense of the evidentiary value of an apology and may be more attuned to the ramifications of evidentiary rules prohibiting or allowing apologies into evidence than are their clients. Thus, the evidential value of an apology and the rules of evidence that determine an apology's admissibility may have a relatively greater impact on how apologies are viewed by attorneys.

Using the pedestrian-bicycle accident scenario described above, I examined the effects of apologies on attorney perceptions and judgments. 28 The study asked attorneys to assume that they represented the client described in the scenario. Attorneys were then asked about their perceptions of the situation and to give their reservation prices, aspirations, and assessments of the fair settlement value of the case.

Attorneys' responses to apologies in the context of this case paralleled the responses of laypeople in previous studies in a number of ways. First, attorneys assessed apologies and the information communicated by the apologies in ways that were similar to the assessments made by claimants—assessing full, responsibility-accepting apologies more positively than they did partial, sympathy-only apologies and assessing both of these more positively than they did no apology. This suggests that attorneys and laypeople made similar judgments about the relative sufficiency of the different types of apologies and
24. Risen \& Gilovich, supra note 21.

25. See Susan Daicoff, Lawyer, Know Thyself: A Review of Empirical Research on Attorney Attributes Bearing on Professionalism, 46 Aм. U. L. Rev. 1337 (1997); Chris Guthrie, The Lawyers' Philosophical Map and the Disputant's Perceptual Map: Impediments to Facilitative Mediation and Lawyering, 6 HARv. NeGOT. L. Rev. 145 (2001); Leonard
L. Riskin, Mediation and Lawyers, 43 OHIO ST. L.J. 29 (1982).

26. Korobkin \& Guthrie, supra note 13.

27. Craig A. McEwen et al., Lawyers, Mediation, and the Management of Divorce Practice, 28 L. \& Soc'y REV. 149 (1994).

28. Jennifer K. Robbennolt, Attorneys, Apologies, and Settlement Negotiation, 13 Harv. Negot. L. Rev. 349 (2008). 
that the apologies conveyed similar information to both groups about the degree to which the offender thought he or she was responsible, the offender's regret, the degree to which the offender would be careful in the future, the degree to which the offender's conduct was offensive, the degree to which the offender respected the client, and the offender's moral character.

In contrast, however, apologies had differing impacts on attorney and claimant evaluations of the offender's responsibility, the client's anger, their own sympathy for the offender, the client's inclination to forgive the offender, and their own judgment that the offender should be punished. While claimants' evaluations tended to be more favorable to the offender following an apology, attorneys' evaluations were not influenced by apologies.

In addition, apologies influenced attorneys' settlement levers in ways that diverge from the ways in which apologies have been shown to influence claimants' settlement levers. Recall that apologies have been shown to decrease laypeople's aspirations and estimates of fair settlement value under some circumstances. In contrast, attorneys whose clients received a full apology set somewhat higher aspirations and made somewhat higher estimates of a fair settlement value than did attorneys whose clients received no apology. For plaintiff's attorneys, this pattern only held when the applicable evidentiary rule made such apologies admissible. That is, settlement levers were higher only when full apologies were offered and those apologies were not made inadmissible by the rules of evidence. This may suggest that attorneys are more attendant to the legal effects of the evidentiary rules than are litigants.

These findings suggest that attorneys have instincts about the functions of apologies that are different from the ways in which their clients react to apologies. Such a divergence is consistent with concerns about a disconnect between the perceptions and interests of attorneys and clients. Many commentators are concerned about the risk that attorneys' focus on the relevant legal rules will dominate the negotiation process and the ultimate settlement of the dispute, to the exclusion of the non-legal interests of the parties. In particular, many have argued that attorneys are inclined to dismiss apologies, despite evidence that they are valued by clients. This may lead attorneys on both sides to resist settlement or to push for trial where their clients might otherwise prefer to settle. Conversely, attorneys may not entirely understand their clients' or opposing clients' resistance to settlement in the absence of apologies. This may lead attorneys on both sides to dismiss claimant requests for apology and may result in a reduced ability to "bring [the] client along" to accept a settlement. ${ }^{29}$ In addition, defense attorneys may advise their clients against apologizing because their perspective suggests that apologies will lead to less favorable settlement terms in addition to any increased liability risk. Any of these disconnects may interfere with attorneys' ability to settle cases to the best satisfaction of their clients.

At the same time, however, it is possible that that the differences in the ways in which apologies affect claimant and attorney settlement levers could serve to bring attorney and client expectations closer in line with each other. Many have argued that plaintiffs sometimes bring with them unrealistic expectations about the value of a case and that plaintiffs' attorneys work to manage such expectations and to "sell" proposed settlements to clients. If this is true, then a decrease in plaintiffs' aspirations and a corresponding increase in their attorneys' aspirations could serve to bring attorney and client aspirations closer together, at least in some cases.

Whether their differing responses to apologies ultimately push attorneys and clients closer together or pull them apart, such divergences are likely to affect the discussion between attorney and client about settlement. Thus, attorneys must give special consideration to how to appropriately advise clients about settlement when an apology is at issue, balancing respect for the interests that clients have that are addressed by apologies while also providing a perspective that helps clients to evaluate the credibility and legal consequences of an apology offered in the context of litigation.

\section{JUDGES AND APOLOGIES}

Judges, of course, also play a role in the settlement of cases. Thus, understanding the ways in which judges respond to apologies is also important. Like the attorneys described above, judges are trained as lawyers, are skilled analysts, and are attentive to legal rights and responsibilities. However, unlike attorneys who represent one side or the other, judges are neutral participants in the dispute.

Judge Andrew Wistrich and Professors Jeff Rachlinski and Chris Guthrie recently conducted a series of studies to examine the effect of apologies on trial judges' decision making. ${ }^{30}$ In two studies, they asked judges to consider the details of a case and to give their assessment of the appropriate settlement value of the case. In both cases, the defendants admitted responsibility for having caused the injuries to the plaintiff, but disputed the amount of damages at issue. Half of the judges were told that the defendant had offered a full, responsibility-accepting apology to the plaintiff during the settlement conference. In both studies, an apology by the defendant did not influence the settlement values provided by the judges. In a third study, the researchers examined the effect of an apology on judges' inclination to discharge a debtor's bankruptcy debt. Again, there were no effects of apology on judges' decisions.
29. See Gerald R. Williams, Negotiation as a Healing Process, $1996 \mathrm{~J}$. Disp. Resol. 1, 24-25 \& n.75 (finding that in 53\% of cases that went to trial, settlement failed due to lawyer inability to "bring [the] client along").
30. Andrew J. Wistrich, et al., Humans Judging Humans: Attribution and Blame in Trial Judges (unpublished manuscript on file with author). 


\section{[I]t is also important for judges conducting settlement conferences to understand how their responses to apologies may differ from both those of the parties and their attorneys.}

Thus, unlike other attorneys, judges did not appear to inflate their assessment of the appropriate settlement amounts in the face of an apology. Conversely, unlike claimants, judges did not appear to moderate their assessment of the appropriate settlement amounts in response to a defendant's apology. One important caveat to note in this regard is that in each of these cases, all judges were told that the defendant had accepted responsibility for having caused the harm. To the extent that either attorneys' expectation of a higher settlement amount or claimants' expectation of a lower settlement are driven by the acknowledgment of responsibility attendant to a full apology, it remains unclear what effect an apology might have on judges' assessments in cases in which liability was not already conceded.

Just as it is important for attorneys to understand how their responses to apologies may differ from those of their clients, it is also important for judges conducting settlement conferences to understand how their responses to apologies may differ from both those of the parties and their attorneys. An awareness of the ways in which apologies are valued by parties and understood strategically by attorneys may enable judges to assist the parties in crafting effective settlements. For example, a judge might simply raise the possibility of an apology with the parties. Or, a judge might structure a settlement conference to provide a context within which a discussion of apologies can occur, paying attention to the functions of apologies for the various parties as well as to the legal implications of apologies.

A judge who introduces the possibility of an apology into the discussion ought to have an understanding of the relevant jurisdiction's apology provisions (see Appendix). This knowledge of the relevant law, combined with an understanding of the potential value of apologies to claimants, the barriers to apologizing for defendants, the potential for manipulation posed by some apologies, and the differing perspectives of claimants, defendants, and attorneys, can position the judge to effectively guide the settlement discussions.

When considering whether to encourage an apology, attention ought to be paid to the context of the dispute. For example, while apologies may have beneficial effects regardless of the state of the evidence, apologies may be both quite valuable to claimants and less risky for defendants to offer when the evidence pointing to liability is relatively clear. Similarly, while apologies are potentially useful in disputes between relative strangers, apologies may be even more valuable and effective when the dispute at hand involves a close or a potentially ongoing relationship_-for example, a doctor-patient relationship, a family relationship, or an employment relationship. Initial conversations might carefully explore the parties' willingness to offer or to receive apologies. The judge can listen for signals that one or both parties would be receptive to such an exchange. It may be wise to tentatively explore the possibility of an apology with the defendant before raising the matter directly with the plaintiff to avoid disappointment if it turns out that the defendant is adamantly opposed to offering one. Consideration might also be given to whether it might be appropriate and productive for both parties to apologize to each other.

In addition, appreciation of what makes an apology effective can be useful in guiding such discussions. Apologies that accept responsibility for having caused harm are more likely to have positive effects and to have bigger impacts than are expressions of sympathy. Apologies may be more effective when offered directly by a defendant to a plaintiff than when mediated through their attorneys. The timing of an apology is also an important consideration. However, the effects of timing on the effectiveness of apologies are complex. On one hand, an apology offered quickly after an injury has occurred may prevent an injury from developing into a grievance or conflict. On the other hand, an apology may ring hollow if it is offered too quickly and without reflection. By the time of a settlement conference, the possibility of an early apology may have passed. Nonetheless, it may be possible to jump start the negotiations with an apology that is offered early in the discussions. Importantly, however, experimental studies have found that apologies can be most satisfactory when the recipient has had a chance to express his concerns and the apologizer has been able to articulate an understanding of the nature of the offense and its consequences. ${ }^{31}$ Thus, the judge might attempt to structure the discussion leading up to an apology with this in mind. Alternately, if it is not possible to secure an apology before reaching a financial settlement, it might be appropriate for a judge to introduce the possibility of arranging for an apology that would come after the financial terms of the deal have been agreed to in principle. 32

Judges might also consider mediation as a process within which apologies can be usefully addressed. Because many states provide that statements made in mediation are not admissible in subsequent legal proceedings, defendants and defense attorneys may be more comfortable offering apologies in mediation. Moreover, the mediation process was designed, in part, to allow parties to play a central role in the negotiation process and to determine for themselves the norms that would govern the resolution of their dispute.

In mediation, the parties themselves can participate directly in the settlement negotiation discussions, assisted by the mediator and while still being advised by their attorneys. A skilled mediator may be able to help create the opportunity for a discussion among the disputants that involves acknowledgment
31. Cynthia McPherson Frantz \& Courtney Bennigson, Better Late Than Early: The Influence of Timing on Apology Effectiveness, $41 \mathrm{~J}$. EXPERIMENTAL Soc. Psychol. 201 (2005).
32. See Howard Raiffa, Post-Settlement Settlements, 2 Negot. J. 1 (1985). 
and apology, to facilitate that discussion, and to facilitate the negotiation that may need to occur between attorney and client. The process allows disputants to introduce non-monetary factors — such as apology - into the discussion. And, the attorneys are still available to advise clients as to the legal consequences of apologies or particular settlement proposals. Mediation, then, can provide either party with an occasion to communicate to the other side their desire to give or to receive an apology and can be a process that is designed to facilitate such conversations.

\section{CONCLUSION}

Apologies may have a role to play in the settlement of legal disputes. Claimants, attorneys, and judges, however, respond to apologies made in the context of litigation in different ways. Judges who understand the nuanced effects that apologies have on the decision making of parties and their attorneys, and who are aware that their own responses may differ from both, will be in a better position to effectively assist in the resolution of legal disputes.

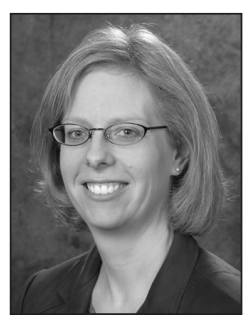

Jennifer K. Robbennolt is a professor of law and psychology at the University of Illinois College of Law, where she is the Guy Raymond Jones Faculty Scholar. She is nationally known in the areas of psychology and law, dispute resolution, and torts. She has served as the secretary of the American Psychology-Law Society and is on the editorial board of two journals, Psychology, Public Policy, and Law and Law and Human Behavior. She recently coauthored a text on Empirical Methods in Law and is one of the coauthors of the casebook Dispute Resolution and Lawyers.

\section{APPENDIX: STATE APOLOGY STATUTES}

Ariz. Rev. STAT. ANN. § 12-2605

CAl. Evid. CODE $\& 1160$ (a)

Colo. Rev. Stat. \& 13-25-135

Conn. Gen. Stat. \& 52-184(d)

Del. Code Ann. tit. 10, §4318

D.C. Code AnN. \& 16-2841

FLA. STAT. \& 90.4026(2)

GA. Code Ann. §24-3-37.1; 735

HAW. REv. STAT. § 626-1

IDAHO CODE \& 9-207

Ind. CODE ANn. § 34-43.5-1

IOWA CODE § 622.31

LA. Rev. Stat. AnN. § 13:3715.5
Me. Rev. Stat. Ann. tit. 24, § 2907

Md. Cts. \& Jud. Proc. Code AnN. \& 10-920

Mass. GEn. Laws CH. 233 §23D

Mo. Rev. Stat. \& 538.229

Mont. Code. Ann. \& 26-1-814

Neb. Rev. Stat. \& 27-1201

N.H. Rev. Stat. AnN. \& 507-E:4

N.C. Gen. Stat. § 8C-4, Rule 413

N.D. Cent. Code § 31-04-12

Ohio Rev. Code Ann. \$2317.43

Okla. Stat. AnN. tit. 63, §

$1-1708.1 \mathrm{H}$
OR. REV. STAT. $\$ 677.082$

S.C. CODE ANN. §19-1-190

S.D. Codified Laws \& 19-12-14

TENN. R. EVID. \& 409.1

Tex. Civ. Prac. \& Rem. Code Ann. $\S 18.061$

UTAH CODE AnN. § 78-14-18

Vt. StAT. AnN. tit. 12, §1912

VA. Code AnN. § 8.01-581.20:1

Wash. Rev. CODE § 5.66.010(1)

W. VA. CODE \& 55-7-11(a)

Wyo. StAT. AnN. \& 1-1-130

\section{AMERICAN JUDGES ASSOCIATION FUTURE CONFERENCES}

\section{Annual Conference}

Denver, Colorado

Westin Tabor Center

October 3-8

$\$ 205$ single/double

\section{Midyear Meeting}

Hilton Head, South Carolina

Westin Hilton Head Island

April 14-16

\$209 single/double
2011 Annual Conference

San Diego, California

Westin Gaslamp

September 11-16

$\$ 199$ single/double

2013 Annual Conference

Kohala Coast, Hawaii

The Fairmont Orchid

September 22-27

$\$ 219$ single/double 